\title{
Bridging the Digital Divide with Universal Access
}

\author{
Dina Dariotist \\ Michael Velasqueztt
}

Dina Dariolis is
pursuing a master of

public administration

at The George

Washington University.

she recelved a

bachelor of arrs in

political science from

The George Washington

University and was a

recipient of the Joshua

Evans Prize for

Excellence in Political

Science. Currently. she

works for the

International Trade

Administration. U.S.

Department of

Commerce.

Michael Velasquez is a

second year MPA

student with a

concentration in

telecommunication

policy. He is also a

Wolcott fellow. A 1989

sraduate of the U.S.

Naval Academy. Mr.

Velasquez curbently

works in milikary

personnel policy for

the Office of the

Secretary of Defense.

This paper proposes a policy in which the public and private sectors collaborate toward the provision of universal access to 


\section{A policy of}

universal access

to information is

an integral

component of

maintaining a

productive

citizenry in the

next millenium. information. For the purposes of this analysis, universal access is defined as affordable access to a national information infrastructure for every citizen requiring its use. The policy is modeled on universal service in the telephone industry and suggests the creation of a universal access fund by the Federal Communications Commission (FCC) for subsidizing companies that make information technology available. The policy addresses regulatory authority of the fund, corporate contributions, tax incentives, and surcharges.

\section{Achieving Electronic Access}

Achieving access is contingent upon the presence of four integral components of information technology: infrastructure, connection, appliances, and education. Infrastructure is the equipment that carries digital and analog signals. Connection is the mechanism that carries information into the appliance. An appliance, such as a computer, translates electronic signals into a usable format for consumers. Education is the necessary training required to use the equipment and services. Infrastructure, connection and appliances comprise the heart of the proposed policy. The administrative details of providing education are too complex to be comprehensively addressed in this policy; however, the importance of training should not be underestimated.

A policy of universal access to information does not assume that everyone will eventually be connected. Until the ideal penetration rate becomes evident in the future, the policy governing universal access to computerized information should aim for the high rates achieved by the telephone industry. ${ }^{1}$

\section{A Citizenry Divided by Accessibility}

While universal access can facilitate the democratic process, lack of access will certainly curtail it. Government agencies at all levels are increasingly using information technology to engage a larger portion of the citizenry. ${ }^{2}$ The use of this technology provides tangible benefits for government by cutting the administrative costs involved in dealing directly with the public and offering a reduction in personnel costs. The benefits are equally lucrative in the private sector. In an effort to increase profits and decrease costs, companies are turning to information technology as a way to reach wider audiences while utilizing fewer resources.

As electronic commerce continues to become an acceptable business practice, computer skills and Internet access will be essential for those who want to be active participants in the economy. Basic services such as mail order shopping, paying bills, obtaining credit information, and performing bank transactions will be easily accessible through information technology. Consumers without access will encounter difficulties in conducting routine commercial activities, and "without basic communications service [are] more likely to become an economic burden on society."3 
Lack of universal access to information poses a significant long-term risk to today's youth. Students who lack access or receive a substandard education will be unable to compete on a national and international level as computer skills become mandatory for most jobs. According to the U.S. Department of Labor, the demand for computer related jobs will double in the next ten years. ${ }^{4}$

According to the Census Bureau, only 36 percent of American adults used computers as of 1993.5 Most adults in 1993 did not receive formal computer training during their primary, secondary, or higher educations. Some employees received basic computer training on the job, but this practice was the exception rather than the rule. Adults who have not had the benefit of computer training face a bleak future in the evernarrowing labor market.

Access to information technology alone will not reduce the socioeco- nomic gap, but the combination of access and education is an essential tool for expanding the opportunities open to people living in poverty. A recent study conducted by the National Telecommunications and Information Administration (NTIA) found that senior citizens in all geographic areas and young people under the age of 25 in rural areas all have low rates of personal computer ownership. According to NTIA, African-Americans living in central cities and in rural areas own the lowest percentage of personal computers. ${ }^{6}$

Advancements in information technology have led to the expansion of what is known as telemedicine. A report to Congress by the NTIA and the Department of Health and Human Services states that:

"telemedicine can improve the delivery of health care in America by bringing a wider range of services such as radiology, mental health services
According to the

\section{U.S. Department}

of Labor, the

demand for

computer related

jobs will double

in the next ten

years.

\section{Internet Growth Projections}

\section{Consumer Households (millions)}

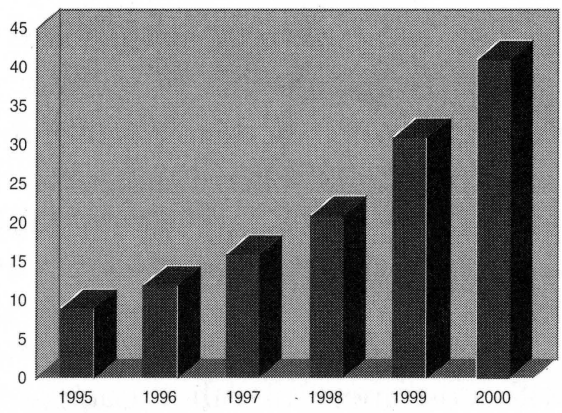

Business Accounts (thousands)

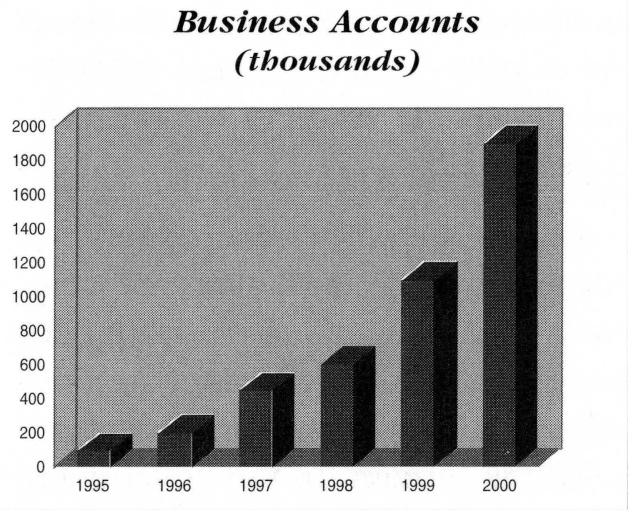


The rapid pace of obsolescence in the computer industry makes the creation of a precise policy difficult. and dermatology to communities and individuals in underserved urban and rural areas. In remote rural areas, where the distance between a patient and health professional can be hundreds of miles, telemedicine can mean the difference between life and death., 7

With proper technology, doctors could see more patients or disseminate information more efficiently, particularly in rural areas. Information technology also helps doctors and scientists share information that can lead to life-saving treatments or cures for terminal illnesses. Those who have electronic access to information will receive a higher quality of health care.

Though a policy of access to information will afford many opportunities, the rapid pace of obsolescence in the computer industry makes the creation of a precise policy difficult. For purposes of this universal access policy, all definitions are based on the information technology that exists and is being used in 1998. This paper refers to "information" in general terms because many types of related technology will be used in the future; in just a few years a "Next Generation Internet" will be created.8 To focus specifically on the Internet or on email limits the vision of the universal access policy.

Many nonprofit organizations are recognizing the importance of information access and are looking for ways to provide technology to those who need it. These efforts may minimize the burden on the government and the information technology industry to provide universal access. The possible effect that charitable organizations may have on universal access is also not considered in this policy.

Finally, the political ramifications from the creation of a universal access policy are not addressed. Special interests and partisan politics will undoubtedly have a significant role in the creation of a universal access policy and its overall effectiveness.

\section{The Precedent for Universal Access to Information}

The role of the government in the evolution of universal telephone service is the precedent for the universal access policy for a national information infrastructure. When the telephone was invented by Alexander Graham Bell in 1876, people generally ignored the new device, but it slowly gained acceptance as people began to recognize its usefulness. In the late nineteenth century, the leadership of American Bell Telephone Company, the predecessor of AT\&T, recognized that the telephone was only as valuable as the number of people who had access to one. In response, the company sublicensed its patent to agents and promoted the iclea that everyone using Bell equipment could call each other. As a result, the first network of telephone customers was created.

Networks of Bell customers, along with customers of other companies, began to be connected to each other across longer and longer distances 
within a state, across state lines, and finally from coast to coast. By the early twentieth century, managers at AT\&T realized that the country's growing dependency on telephony, the umbrella term for the use of telephone equipment and service, required a policy that reflected both corporate and individual interests.

In the AT\&'T Annual Report of 1910, Theodore Vail, president of the company, articulated the concept of universal service as:

"'One System,' 'One Policy,' 'Universal Service': No aggregation of isolated independent systems not under common control, however well built or equipped, could give the country the service. One system with a common policy, common purpose, and common action; comprehensive, universal, interdependent, intercommunicating like the highway system of the country, extending from every door to every other door, affording electrical communication of every kind, from every one at every place to every one at every other place."

Vail's definition of universal service was simple. Every customer who was linked to a universal network could talk to every other customer on that network. Vail also believed that the infrastructure requirements of the telephone business-setting up poles, stringing wires, and establishing switchboards-meant that a single company, namely AT\&T, should be responsible for providing universal service.
Around the time Vail announced AT\&T's universal service policy, federal regulation of the telephone business began. Universal service, which had begun as a marketing concept for selling telephone service, quickly became a regulatory ideal. In 1934, Congress passed the communications act which established the Federal Communications Commission. In addition to its other responsibilities, the FCC monitored AT\&T's provision of universal service.

Although universal service was the goal, the economic reality throughout the twentieth century was that not all customers could afford to pay the cost of telephone service. For example, a clerical worker in a rural area has less ability to pay for telephone service than a wealthy banker in Manhattan, and providing service in rural areas is often more expensive than providing service in Manhattan. To address these problems, AT\&T, along with federal and state regulators, created a system of subsidies whereby low-cost, high-revenue service (long distance calls) would subsidize high-cost, low-revenue service (local calls). Revenue gained from business customers in Manhattan might be used to offset the cost of providing residential service to lowincome workers in rural areas.

The elaborate system of subsidies for low-density areas worked effectively when AT\&T was a unified company, but when divestiture occurred and the company was broken up on January 1, 1984, universal service was threatened. The subsidy policy,
Universal service, which had begun

as a marketing concept for selling telephone service, quickly became a regulatory ideal. 
The newly

created universal

access fund

would derive its

income from a

combination of

regular

contributions

from service

providers and a

user fee for new

entrants. which had become central to the provision of telephone service, was prohibited by the court order mandating divestiture, and alternative measures became necessary. These substitute measures worked well, and universal service remains the standard of service in the telephone business today.

\section{Information Technology: The Ever-Changing Present}

The predecessor of the Internet was known as ARPANET and was created during the 1960 s by the Department of Defense's Advanced Research Projects Agency as a way "to make the U.S. communications infrastructure resistant to nuclear attack." ${ }^{10}$ The government and a few select universities used the network primarily for research. ARPANET was ultimately replaced by the National Science Foundation's NSFNET in 1986.11 The National Science Foundation (NSF) eventually joined with MCI and IBM to improve on the technology and create the Internet in its present incarnation. As a result of this partnership, commercial use of the Internet became a reality for the first time. The NSF still plays a role in the development and maintenance of the Internet; however, the government and the NSF have contracted out and given much of the responsibility for the technology to the private sector and established the framework of information access that currently exists. ${ }^{12}$ Information technology developed as a free market, unregulated enterprise, and the advance of the Internet into the private sector led to the creation of several companies that provide information technology and services.

When Congress revamped telecommunication regulation in 1996, the increasing importance of information access was addressed through an expansion of the scope of universal service in the telephone industry. Section 254 of the Telecommunications Act of 1996 requires that the government work with the private sector to ensure that public institutions such as schools, libraries and health care facilities are equipped with the necessary information technology. However, the act still follows the conventional model of universal service while briefly mentioning "advanced telecommunications and information services. ${ }^{13}$

\section{Proposed Policy}

Universal service in the telephone industry provides a good beginning framework, but the scope of the Telecommunications Act is too narrow to provide an effective regulatory mechanism for universal access to information. Under the proposed policy of universal access, various regulatory agencies will be responsible for determining categories of companies required to contribute to a fund and companies eligible to receive support from that fund. Following the enactment of universal access regulation, these same agencies will develop a definition of the basic information service that should become universally available. Additionally, the government will develop incentive programs for the provision of low-cost appliances, basic training, and computer 
literacy programs. Market forces alone will not ensure that "consumers in all regions of the Nation, including low-income consumers... have access to telecommunications and information services." 14

\section{Universal Access Fund}

Section 254 of the Telecommunications Act of 1996 states that "access to advanced telecommunications and information services should be provided in all regions of the nation."15 Federal and state regulators presumably agree with this congressionallyimposed mandate. The politics of the regulatory agencies in Washington and their constant negotiations with Congress over their budgets suggest that the agencies have no choice but to agree. Accordingly, federal and state regulators of the universal access fund will need to find a way to pay for the cost that comes with information accessibility. The original universal service fund for the telephone business provides a workable model.

The newly created universal access fund would derive its income from a combination of regular contributions from service providers and a user fee for new entrants. Similar to the model of the Universal Service Fund, both the FCC and the state regulatory authorities (SRA) would calculate a formula for contributing to the fund based on company revenues, As a federal policy-making agency, the FCC would define the categories of companies required to contribute to this fund and the SRAs would name specific companies that meet the FCC's definition and ensure their compliance:

With these distribution mechanisms in place, the user fee, a $\$ 10$ per year annual surcharge on domain names, would be assessed on companies that currently pay $\$ 70$ for the first two years and $\$ 35$ annually thereafter for domain names. If the current registration rate of 165,000 new applicants for domain names each month continues, the total contribution will exceed $\$ 18.5$ million in annual subsidies. The number of domain registrants doubled from 1996 to 1997, and continued growth is expected. ${ }^{16}$

The creation of a nonprofit corporation to manage the fund and distribute subsidies according to FCC and SRA policy is a key component of a universal access policy. The FCC designated the Universal Service Administrative Company (USAC) as a temporary administrator of the universal service fund. ${ }^{17}$ In addition to the USAC, two other independent, nonprofit entities were created to oversee the most recent additions to universal service support: the Schools and Libraries Corporation (SLC) and the Rural Health Care Corporation (RHCC), ${ }^{18}$ This policy requires the formation of a third nonprofit entity under USAC to oversee universal access-the Universal Access Corporation (UAC).

The proposed UAC would include members of the USAC, SLC, and RHCC, as well as representatives of service providers, infrastructure companies, and domain registration managers. The arrangement of the UAC
The creation of a

nonprofit

corporation to

manage the fund

and distribute

subsidies

according to $\mathrm{FCC}$

and SRA policy is

a key component

of a universal

access policy. 


\section{At a minimum,} service should

include access to

basic government

services,

educational

opportunities,

and other public

provisions with

the possibility of

expanding the

list based on the

criteria of "public

interest,

convenience, or

necessity." under the USAC takes advantage of the current organizational structure, thus enabling a smooth and rapid implementation of universal access to information. Ultimately, universal access will become a part of the universal service concept.

Another organization that is important to the universal access fund is the already established Federal-State Joint Board, which was originally created to make recommendations for expanding universal service support. The UAC would collect funds from those companies designated by the SRAs and then distribute the money based on the requirements established by the Joint Board. The Board would recommend a method to classify those companies eligible for universal access support and recommend the amount of subsidy necessary. Companies that are eligible for support, Internet service providers (ISP), and other information providers, must demonstrate the amount of service provided to consumers in need to receive subsidies directly from the UAC.

In deciding eligibility and the level of support, the Joint Board should rely on the precedent set in the Lifeline program, which provides a monthly reduction in telephone service charges to low-income consumers. To qualify for Lifeline support, consumers must meet income criteria established by SRAs. Currently, recipients' needs are demonstrated by participation in one or more of the following programs: Medicaid, food stamps, Social Security Income, federal housing as- sistance, or the Low-Income Energy Assistance Program. ${ }^{19}$

\section{What Citizens Can Expect}

Under this policy, the Joint Board would create a definition of the services to be covered by universal access subsiclies. Given the rapid pace at which technology-in terms of both information and equipment-is growing, the Joint Board will need to update its definition of basic service frequently, recognizing the "evolving level of telecommunications. ${ }^{20}$ At a minimum, service should include access to basic government services, educational opportunities, and other public provisions with the possibility of expanding the list based on the criteria of "public interest, convenience, or necessity."21

The convergence of telecommunication services is on-going: The 1996 Telecommunications Act allows telecommunication companies to enter other telecommunication service markets. For example, some companies offer Internet access, local telephone service, and cable television for one monthly price. Analysts expect this trend to continue. Already, Internet content providers such as Prodigy, CompuServe, and MSN differentiate between basic and enhanced service. The proposed policy would ensure that basic information service is affordable while leaving consumers the option of subscribing to a number of additional services, much like people choose to have voice messaging or long distance in addition to basic telephone service. 
The option for consumers to design their own telecommunication packages is a selling point of the proposed policy. A 1995 study suggests that consumers are already assembling different combinations of media and information to meet their needs. In Camden, New Jersey, 50 percent of households without telephone service had cable service and 75 percent had VCR's. ${ }^{22}$ In Texas, 40 percent of those without telephones had cable and 95 percent owned televisions. ${ }^{23}$ Based on these figures, it is possible that people will choose on-line services over other telecommunication options.

\section{Appliances}

Connection is useless without the appliance to view and synthesize the information. Although the average cost of a new computer is approximately $\$ 2000$, a new computer is not required to access the information superhighway-used computers are equally effective. Presently, no economic incentive exists to recycle used computers. At best, used computers sell for $\$ 20$ if operable; as scrap, they are worth only three cents per pound. ${ }^{24}$ A Tufts University study estimated that of the nearly 14 to 20 million computers retired annually, almost 75 percent end up in stockpiles whereas only 10 percent are reused or recycled. 25 To promote the availability of appliances, an income tax exemption of $\$ 50$ would be offered to every taxpayer who donates an older but usable computer to the universal access fund.
Community-based organizations (CBO) which are sensitive to community needs, play a critical role in making available the benefits of advanced telecommunication services and networking by distributing used computers. ${ }^{26}$ The inclusive nature of universal access will require the involvement of organizations closest to the end user. CBOs can provide in-house training or establish training centers accessible to low-income and rural citizens. The California Public Utilities Commission pioneered the concept of including $\mathrm{CBOs}$ by offering them discounted rates for connection to the information infrastructure. Recognizing the importance of CBOs, the California Commission stated "because of their economic and social impact... community...institutions must be positioned to be early recipients of the benefits of the information age," 27

\section{Benefits of Universal Access}

Since the value of the network increases with the size of the network, it is in the best interest of those organizations providing service to keep the cost of access low for information consumers. Given that the penetration rate of personal computers approaches 60 percent and access to the Internet is estimated at only 20 percent of the population, tremendous growth potential exists. If as many people choose to receive universal access support as have chosen Lifeline assistance, organizations connected to the network can expect to see more than 5.7 million low-income people connected. ${ }^{28}$
The inescapable

future reliance

on computers for

a vast array of

citizenship

functions makes

an inclusive

policy essential. 
The government

must make

access to, and

understanding of,

computer

services a

national priority.
Although advancements in the computer industry will continue to exert a downward pressure on computer prices, universal access will accelerate that downward trend. A used-computer tax exemption can be adopted quickly and provicles an incentive that aids in connecting more users to the information superhighway.

According to one scholar, microprocessors will double in power and halve in costs every six months. Thus, in ten years, top-of-the-line, entry level appliances will be 20 to 100 times more powerful and cost around $\$ 500 .{ }^{29}$ As technology develops, more appliances will be available to low-income users and appliances will contain better technology and have longer life cycles. For example, Oracle has already designed a network computer with fewer components than previous versions but with greater capabilities based on connection to a network. Phillips Electronics markets a WebTV costing around $\$ 300$ that provides access to the information infrastructure through a familiar and low-cost device, the television. 30

\section{Challenges of Universal Access to Information}

If universal access to information is realized, use of the information infrastructure, including the telephone network that provides access to the computer network, could quadruple. Some Bell operating companies, the traditional providers of local telephone service, have expressed their concern with the current usage level by asking the FCC to charge Internet service providers (ISP) a per-minute fee for access to the telephone network. ${ }^{31}$ ISPs would undoubtedly pass these increased costs to the consumer. Moreover, increased access fees could require increased subsidies from the universal access fund to keep low-income and isolated, rural consumers connected.

The regulatory burden on the computer industry is another disadvantage of the universal access to information policy. The requirement to document service provided to low-income and rural consumers levies a substantial regulatory burden on information proviclers and raises the cost of providing service. This new regulatory scheme also increases the administrative burden on the FCC and the SRAs who must oversee the new program.

\section{Conclusion}

The importance of access to a national information infrastructure directly corresponds to today's proliferation of computer goods and services. Although access to the information superhighway through public institutions such as libraries and schools-those beneficiaries of the mandated universal service contained in the Telecommunications Act of 1996-will be helpful, a true change requires a more pervasive approach. The inescapable future reliance on computers for a vast array of citizenship functions makes an inclusive policy essential. In the absence of such a policy, lawmakers are sealing the fate of a new generation of marginalized Americans. 
To prevent the problems associated with computer illiteracy-inclucting social and political isolation-the government must make access to, and understanding of, computer services a national priority. This proposed policy seeks to head off the possibility of a citizenry divided by accessibility. The success of this universal access policy, which guarantees an affordable link to the national information infrastructure, depends on three things: the regulatory initiative of the FCC and the state regulatory agencies, contributions of appliances by the industry and private citizens, and a far-reaching initiative to acquaint American citizens with the language of the future. This policy paper is an invitation to lawmakers to engage each other and the American public in this dialogue. 4

\section{Notes}

†Dina Dariotis-I want to give special thanks to Amy Downey for her patience and hard work. I am grateful to Michael Velasquez for being a wonderful co-author. Thank you to Professor Jill Kasle and Dr. Kathryn Newcomer for their constant faith in my abilities. I owe many thanks to my mother, Joanne Dariotis, for being a source of strength and encouragement. I dedicate this article to my late father, Dimitrios Dariotis, for his belief in the value of education
Hichotel Velsasquez-I wish to thank the following people: our editor, Amy Downey, for her patience, guidance, diplomacy and enthusiasm; Dina Dariotis, whose drive and passion enabled this article to come to life; Rachel Stein, for her confidence in us; Jill Kasle, for her succinct advice and absolute confidence; and Chris Sterling and John Gamlya for sharing their inclustry expertise. Finally, I would like to acknowledge the contributions of the two most important people in my life: my father, who taught me the value of perseverance and hard work and who commands my utmost respect; and Mary Herbenick, whose unconditional love and support empower me.

11997 Monitoring Report, CC Docket No. 97-339, May, 1997.

${ }^{2}$ Local government agencies have started placing information kiosks in public areas, which allow people to apply for government jobs, renew automobile licenses, order birth certificates, and learn about job-training programs. See Benton Foundation, "Impact on American Life and Work"; avatiable from http://www.benton.org/Library/KickStart/nati on.impact.html; INTERNET.

3 Marlin Blizinski and Jorge Reina Schement, "Rethinking Universal Service: What's On the Menu" (paper presented at the 24th Annual Telecommunications Policy Research Conference, Solomons, MD, 5-7 October 1996), 8-9.

4 The Policy Community Online, "Issue of the Week"; available from http://www.policy. com/issuewk/98/0119/011998a,html;

INTERNET.

5 U.S. Census Bureau; available from http://www.census.gov/population/compute r/compuseb,txt; INTERNET,

6 National Telecommunications and Information Administration, "Falling Through the Net: A Survey of the 'Have-Nots' in Rural and Urban America," July 1995; available from http://www.ntia.doc.gov/ ntiahome/fallingthru.html; INTERNET.

7 NTIA, "Telemedicine Report to Congress," 31 January 1997; available from http://www. ntial.cloc.gov//reports/telemed/execsum.htm; INTERNET:

\section{This policy paper}

is an invitation to

lawmakers to

engage each

other and the

American public

in this dialogue. 
8 Two consortiums, comprised of Federal government agencies, various academic institutions, and industry partners, are working on two separate infrastructure development programs - Next Generation Internet (NGI) and Internet2 (12) - that, in the next $3-5$ years, will operate networks between 100 and 1000 times faster than today's Internet. See George Strawn, "Next Generation Internet (NGI) Initiative," (a briefing presented to the Congressional Internet Caucus), 13 June 1997; available from http://www,ngi.gov/talks/strawn13JUn97/; INTERNET.

9 Brennon Martin, "Universal Service and Information Poverty: A New Look at an Old Problem"; available from http:/ www.weber. u. washinton edu/ brennon/html/papers/tis? 6.html; INTERNET.

10 Philipp Afeche, "A Note on the Internet." Graduate School of Business, Stanford University, Paper S-OIT-15, 1996, 1.

11 Ibid., 2.

12 Ibidl. 3 .

13 Telecommunications Act, U.S. Code, vol. 47, sec, 254 (b) (2) (1996). (3).

144 Telecommunications Act, sec. 254 (b)

15 Telecommunications Act, sec. 254 (b) (1).

16 Network Solutions Incorporated Press Release, "Network Solutions Announces Record 1997 Fourth Quarter and Annual Revenue and Earnings," 10 February 1998; available from http://www.netsol.com/ news/pr_19980210.html; INTERNET.

17 Federal-State Joint Board on Universal Service, CC Docket No. 96-45, Report and Order, 62 Fed. Reg. 32862.

18 Federal-State Joint Board on Universal Service, Changes to the Board of Directors of the National Exchange Carrier Association, Inc., Report and Order and Second Order on Reconsideration, CC Dockets No. 97-21, 9645, FCC 97-253.

19 The FCC uses these programs to determine eligibility for the Universal Service Progtam for Low-Income Consumers.
20 Telecommunications Act, sec, 254 (c) (1).

21 Telecommunications Act, sec. 214 (e) (2).

22 Jorge Reina Schement, Rebecca R. Pressman, and Laurance Povich, Transcending Access Toward a New Universal Service (paper presented at "Universal Service in Context: A Multiclisciplinary Perspective," conference at New York Law School, 6 December 1995); available at http://www.benton,org/ Policy/Uniserv/Conference/transcend.html; INTERNET.

23 Ibid.

24 Ibid.

25 Keith Myers, "Computers Stockpiled for Reuse," New York Times, 12 March 1998; available from http://www.infomagic.com/ -abyte/byte/news/articles/news.26; INTERNET.

26 Carey Goldberg, "Where Do Computers Go When They Die?" New York Times, 12 March 1998; available from http://www. nytimes,com; IN'TERNET.

27 The Columbia, South Carolina Housing Authority places clonated computers in public housing. Similar programs operate in California, Virginia, and North Carolina. One nonprofit company provicles used computers to Indian reservations in Arizona. See http://www.infomagic.com/ abyte/byte/new s/articles; INTERNET.

28 California Public Utilities Commission, Mandates of Assembly Bill 3643, No. 9610066, 1996.

291997 Monitoring Report, CC Docket No. 97-339, May, 1997.

30 Carol A. Twigg and Robert C. Heterick, Jr., "The NLII Vision: Implications for Systems and States"; available from

http://educom.edu/program/nlii/keydocs/pu blicpolicy.html; INTERNET.

31 Various television advertisements have been run on national and cable networks advertising this price.

32 FCC, "The FCC, Internet Service Providers, and Access Charges," 7 Jan, 1998; available from http://www,fcc.gov/Bureaus/ Common_Carrier/Factsheets/ispfact.html; INTERNET. 


\section{Bibliography}

Afeche, Philipp. "A Note on the Internet." Paper S-OIT-15. Graduate School of Business, Stanford University, 1996.

Anderberg, Anthony. "History of the Internet and Web." 1997. Available from http://www.dsu.edu/ anderbea/ history/; INTERNET.

Anderson, Robert H. et. al. Universal Access to E-Mail: Feasibility and Sociotal Implications. Santa Monica: Center for Information Revolution Analysis, Rand, 1995.

Blizinski, Marlin and Jorge Reina Schement. "Rethinking Universal Service: What's On the Menu." Paper presented at the 24th Annual Telecommunications Policy Research Conference, Solomons, MD. 57 October 1996.

Browning, John, "Universal Access'-An Idea Whose Time is Past." Wired Ventures, ltd. Copyright 1994. Available from http://www.virtualschool.edu/mon/Elec tronicFrontier/UnivAccess'imeIsGone.ht $\mathrm{ml}$; INTERNET.

California Public Utilities Commission, Mandates of Assembly Bill 3643, No. 9610066, 1996.

Clinton, William J. "1998 State of the Union Address." 27 January 1998. Available from http://www.pub.whitehouse.gov/ urires/L2R?pdi://oma.eop.gov.us/1998/0 1/27/11.text.1; INTERNET.

Cohill, Andrew Michael and Andrea Lee Kavanaugh, ed. Community Networks: Lessons from Blacksburg, Virginia. Boston: Artech House, 1997.

Dertouzos, Michael. What Will Be. San Francisco: Harper Edge, 1997.

Federal Communications Commission. "The FCC, Internet Service Providers, and Access Charges." 7 January 1998. Available from http://www.fcc.gov/ Bureaus/Common_Carrier/Factsheets/is pfact.html; INTERNET.

Federal-State Joint Board on Universal Service, CC Docket No. 96-45, Report and Order, 62 Fed, Reg, 32862.
Federal-State Joint Board on Universal Service Changes to the Board of Directors of the National Excbange Cartier Association, Inc. Report and Order and Second Order on Reconsideration, CC Dockets No. 97-21, 96-45, FCC 97-253.

Goldberg, Carey. "Where Do Computers Go When They Die?" New York Times. 12 March 1998. Available from http://www.nytimes.com; INTERNET.

Hadden, Susan. "Universal Service Policies for the Public Interest Sector," Communications Policy Working Paper, \#3, Benton Founclation. 10 December 1996. Available from http://www,benton,org/Liblary/Policyo ps/working3.html; INTERNET.

Hudson, Heather: "Universal Service: The Rural Challenge Changing Requirements and Policy Options." Policy Working Paper, \#2, Benton Foundation. 10 December 1996. Available from http://www.benton.org/Library/Rural/w orking2.html; INTERNET.

Kahn, Robert E. "The Role of Government in the Evolution of the Internet." Available from http://www.nap.edu/reaclingroom/ books/newpath/cliap2.html; INTERNET.

Kristula, Dave. "The History of the Internet." March 1997. Avalable from http:/t www. davesite.com/webstation/nethistory.html; INTERNET.

Martin, Brennon. "Universal Service and Information Poverty: A New Look at an Old Problem." Available from http:// www.weber.u.washinton.edu/ b brennon /html/papers/tis $96 . h \mathrm{hml}$;NTERNET.

Myers, Keith. "Computers Stockpiled for Reuse." New York Times, 12 March 1998. Available from http://wrww.nytimes.com; INTERNET.

Nakamura, David. "Call of Problems for Computer Have-Nots." The Washington Post. 11 March 1998. Available from http://www.washingtonpost.com/wpsrv/frompost/march98/computers11. html; INTERNET, 
National Telecommunications and information Administration, "Falling Through the Net: A Survey of the HaveNots' in Rural and Urban America." July 1995. Available from http:/www.ntia. doc.gov/ntiahome/fallingthru.html; INTFENET.

"Telemedicine Report to Congress." 31 January 1\%97. Available from htp:/ www ntiadex.gov//reports/telemed/exe s'sum.html; INTERNET:

Network Solutions Incorporated. "Network Sislutions Announces Record 1997 Fourth Quarter and Annual Revenue and Earnings," 10 February 1998; available from http:/ www netsol.com/news/ pr_19980210.html; INTERNET.

"Network Solutions Announces Elimination of Infrastructure Fees for Domain Name Registrations." 16 March 1998; available from http:/ www netsol com/news/pr_19980316.html; INTERNET.

NII 2000 Steering Committee, Computer Science and Telecommunications Research Board, National Research Council. The Unpredictable Certainty: Information Infrastructure through 2000. Washington D.C.: National Academy Press, 1996.

1997. Monitoring Repont. CC Docket No. 97 339, May, 1997.

The Policy Community Online. "Issue of the Week." Available from http:/www. policy.com/issuewk/98/0119/011998a.ht ml: INTERNET.

Schement, Jorge Reina, Rebecca R. Pressman. and Laurance Povich. Transcending Access Touard a New Universal Service. Paper presented at "Universal Service in Context: A Multidisciplinary Perspective," conference at New York Law School, 6 December 1995. Available from http//www Lenton.org/Policy/ Uniserv/Conference/transcend.html; INTERNET

Schement, Jorge Reina and Terry Curtis. Tendencies and Tensions of the Information Age: The Production and Distribution of Information in the Lniled Statex. New Brunswick, NY: Tipansaction Publishers, 1995.
Strawn, George. "Next Generation Internet (NGI) Initiative." A briefing presented to the Congressional Internet Caucus. 13 June 131997 . Available from http:// www.ngi.gov/talks/strawn-13Jun97/; INTERNET,

Telecommunications Act U.S. Code. Vol. 47, hecs, $214-260(1096)$.

Twigg, Carol A. and Rohert C. Heterick, Jr' "The NLII Vision: Implications for Systems and states." Available from http:/educom.edu/program/nlii/keydox s/publicpolicy.html; INTERNET.

United States Advisory Council on the Information Infrastructure. "Impact on American Life and Work." Available from http-//www.benton.org/Library/Kickstart /nation.impact.html; INTERNET.

United States Census Bureatu. "Level of Access and Use of Computers: 1984, 1989, and 1993." Available from http:/www.census.gov/population/com puter/compuseb.txt; INTERNET. 